\title{
FUNGSI SINTAKSIS DAN PERAN SEMANTIK ARGUMEN FRASA VERBA BAHASA BALI
}

\author{
Agus Ari Iswara \\ Universitas Warmadewa \\ agus_ari_iswara@yahoo.co.id
}

\begin{abstract}
Abstrak
Penelitian ini bertujuan untuk menganalisis mengenai fungsi sintaksis dan peran semantik argumen frasa verba Bahasa Bali. Data pada penelitian ini berupa data tulis. Pengumpulan data dilakukan dengan metode simak. Dalam penelitian ini menggunakan Teori Struktural dan Teori Peran dan Acuan. Hasil analisis data menunjukkan bahwa struktur FVBB dapat berupa FV sederhana dan FV kompleks. FVBB sederhana terdiri dari unsur pusat (head) saja tanda modifier. FVBB kompleks terdiri dari, 1) FV endosentrik atributif yang terdiri atas modifier dan head, 2) FV endosentrik koordinatif yang terdiri dari dua verba yang dihubungkan oleh konjungsi (V KONJ V). FVBB kompleks yang terdiri dari modifier dan head dapat diisi oleh $(\mathrm{ADV}+\mathrm{V}),(\mathrm{PK}+\mathrm{V}),(\mathrm{NEG}+\mathrm{V}),(\mathrm{ADV}+\mathrm{NEG}+$ $\mathrm{V}),(\mathrm{ASP}+\mathrm{V}),(\mathrm{ASP}+\mathrm{ADV}+\mathrm{V}),(\mathrm{ADV}+\mathrm{ASP}+\mathrm{V}),(\mathrm{MOD}+\mathrm{V}),(\mathrm{MOD}+\mathrm{ADV}+\mathrm{V}),(\mathrm{MOD}+\mathrm{V}$ $+\mathrm{ADV}),(\mathrm{ASP}+\mathrm{NEG}+\mathrm{MOD}+\mathrm{V})$ dan $(\mathrm{NEG}+\mathrm{MOD}+\mathrm{V})$. Berdasarkan fungsi sintaksisnya, di dalam kalimat, FVBB pada umumnya berfungsi sebagai predikat yang merupakan inti dari kalimat. Dalam penelitian, ditemukan bahwa dia juga dapat berfungsi sebagai subjek, objek, pelengkap, keterangan, dan apositif. Argumen yang diikat oleh FVBB di dalam kalimat memiliki peran semantis yang dipengaruhi oleh FV yang mengikatnya. Berdasarkan toeri $R R G$, pada BB ditemukan peran umum dari argumen adalah sebagai actor dan undergoer dengan peran khususnya masing-masing. Peran khusus dari actor dan undergoer yang ditemukan dalam BB, yaitu agen, pengakibat, pengalami, alat, pasien, tema, asal, dan lokatif.
\end{abstract}

Kata Kunci: head, modifier, fungsi sintaksis, argumen, peran.

\begin{abstract}
This research aims at analyzing about the syntactic function and semantic role of the argument of Verb Phrase. This research uses written data. The data was collected through reading method. Structural Theory and Role and Reference Grammar Theory were applied in this research. The research shows some results. In Balinese there are simple verb phrase and complex verb phrase. The simple verb phrase consists of only one head. Complex verb phrase is divided to 1) endocentric attributive which consist of modifier and head, 2) endocentric coordinative which consists of verbs linked by conjunction ( $V$ CONJ V). Based on the research, it is found that endocentric attributive verb phrase can be construct of $(A D V+V),(F Q+V)(N E G+V),(A D V+N E G+V),(A S P+V)$, $(A S P+A D V+V),(A D V+A S P+V),(M O D+V),(M O D+A D V+V),(M O D+V+A D V),(A S P+$ $N E G+M O D+V)$ and $(N E G+M O D+V)$. In a clause, the main syntactic function of Verb Phrase of Balinese usually as a predicate, but in this research, it also has function as subject, object, complement, adverb, and appositive. This research also found that the argument of verb phrase of Balinese generally has semantic role of actor and undergoer. Their special role can be divided into agent, effectors, experiencer, patient, them, source, and locative.
\end{abstract}

Keywords: head, modifier, syntactic function, argument, semantic role.

\section{PENDAHULUAN}

Bahasa Bali yang selanjutnya disebut $\mathrm{BB}$, adalah bahasa yang masih terpelihara, dibina, dan digunakan oleh penuturnya da- lam berbagai aspek kehidupan masyarakat khususnya oleh masyarakat daerah Bali. Bahasa yang memiliki aksara yang disebut Aksara Bali ini merupakan salah satu baha- 
sa daerah yang tetap digunakan sebagai sarana sosialisasi dan alat komunikasi lisan maupun tulisan. Sebagai bahasa lisan, bahasa ini digunakan dalam proses komunikasi baik dalam topik resmi maupun tidak resmi (Bawa, 1991: 1).

Menurut Artawa (2004: 2), BB dapat dikatakan sebagai bahasa daerah yang besar apabila dilihat berdasarkan jumlah penuturnya karena digunakan oleh kurang lebih tiga juta penutur. Jumlah tersebut merupakan jumlah masyarakat penutur yang cukup banyak. BB memiliki ciri khusus yang menarik yakni memiliki dua variasi, yaitu Bahasa Bali Alus dan Bahasa Bali Kasar (Pastika, 1999: 1). Variasi tersebut dapat dibedakan berdasarkan tataran leksikon dan sedikit dalam tataran morfologi serta sintaksisnya. BB Alus biasanya digunakan pada situasi dan kondisi formal serta digunakan untuk berkomunikasi dengan orang yang dianggap memiliki status sosial yang tinggi dan dihormati serta dianggap suci. Sedangkan BB Kasar digunakan dalam pergaulan sehari-hari dengan orang-orang yang kita setarakan dengan diri kita.

Sebagai bahasa daerah, BB berkedudukan dan berfungsi penting bagi masyarakat karena bahasa ini merupakan bahasa ibu atau bahasa pertama yang digunakan dan dipelajari di lingkungan tempat tinggal melalui interaksi dengan masyarakat (Samsuri, 1987:7). Disamping itu, BB juga merupakan lambang identitas daerah Bali, sebagai lambang kebanggaan masyarakat daerah Bali, juga sebagai sarana pengembangan masyarakat dan kebudayaan daerah.

Sehubungan dengan pembinaan dan pengembangan terhadap $\mathrm{BB}$ sebagai bahasa daerah, sejak dulu hingga saat ini, masih dilakukan penelitian-penelitian atau kajian ilmiah terhadap BB oleh para ahli, khususnya penelitian mengenai satuan-satuan linguistiknya. Seperti bahasa pada umumnya, dalam BB juga dikenal adanya satuan linguistik yang disebut morfem, kata, frasa, klausa, dan kalimat. Struktur dari frasa, klausa, dan kalimat merupakan objek kajian sintaksis. Ramlan (1995: 22) dalam bukunya Ilmu Bahasa Indonesia 'Sintaksis' telah menjelaskan hubungan satuan linguistik tersebut. Dikatakannya bahwa satuan kalimat terdiri atas unsur-unsur yang berupa klausa; satuan klausa terdiri atas unsurunsur yang berupa frasa; dan satuan frasa terdiri atas unsur-unsur yang berupa kata.

Frasa merupakan salah satu satuan linguistik yang cukup menarik untuk diteliti. Frasa merupakan satuan linguistik yang lebih besar dari kata dan lebih kecil dari klausa dan kalimat. Frasa dapat dikatakan sebagai kumpulan kata nonpredikatif yang artinya di antara kedua kata itu tidak ada yang berkedudukan sebagai predikat dan 
hanya memiliki satu makna gramatikal. Frasa memiliki beberapa ciri, yaitu frasa terbentuk atas dua kata atau lebih dalam pembentukannya, menduduki fungsi gramatikal dalam kalimat, mengandung satu kesatuan makna gramatikal, dan bersifat nonpredikatif.

Ketertarikan penulis terhadap frasa menimbulkan pertanyaan-pertanyaan mengenai frasa verba Bahasa Bali yang slanjutnya disebut FVBB. Tetapi permasalahannya, dalam buku-buku teori Bahasa Bali belum dibahas secara mendalam mengenai FVBB. Sehingga penulis merasa FVBB masih perlu untuk diteliti. Selain itu dalam dunia penelitian, penelitian mengenai FVBB juga masih sangat jarang. Hal ini dibuktikan dengan sulitnya menemukan hasil penelitian tentangnya untuk dijadikan kajian pustaka sebagai acuan untuk penelitian ini. Hal ini semakin memberikan celah bagi penulis untuk meneliti FVBB.

Seperti satuan linguitik yang lain tentunya frasa verba juga memiliki struktur. Dalam hal struktur FVBB, penulis hendak mengetahui apakah teori dari Quirk yang menyatakan adanya frasa verba sederhana dan kompleks dapat berterima jika diaplikasikan pada BB, kemudian seperti apakah strukturnya dalam kalimat aktif dan pasif BB. Selain struktur, masing-masing frasa verba mengisi fungsi sintaksis dalam ka- limat BB, hanya saja perlu diteliti fungsi apa sajakah yang bisa diisi olehnya. Hal tersebut juga menjadi permasalahan yang ingin penulis teliti lebih jauh. Kemudian, dalam tataran semantik, juga akan dibahas mengenai peran argumen FVBB. Hal tersebut juga masih terbuka untuk diteliti lebih jauh, sehingga penulis memilih masalahmasalah tersebut untuk dibahas dalam penelitian ini.

\section{KONSEP DAN KERANGKA TEORI KONSEP}

\section{FRASA VERBA SEDERHANA}

Frasa verba sederhana adalah frasa verba yang terdiri dari satu kata kerja pokok (head) saja. Dalam Bahasa Inggris, bentuk ini dapat ditemui pada kalimat berbentuk present, past, imperative, dan subjunctive. Contoh frasa verba sederhana menurut Quirk dapat dilihat pada kalimat He works hard; He worked hard; Work harder!, It is important that he work hard. Frasa sederhana hanya berterima pada teori generatif, tapi tidak berterima pada teori non generatif. Hal ini karena teori non generatif menyatakan frasa merupakan gabungan dua buah kata atau lebih, bukan satu kata saja.

\section{FRASA VERBA KOMPLEKS}

Menurut Quirk, frasa verba kompleks adalah frasa verba yang terdiri dari satu atau lebih modifier yang mendampingi head. 
Artinya, dalam satu konstruksi frasa verba, sebuah head memiliki unsur pendamping yang jumlahnya bisa lebih dari satu. Kata yang dapat menduduki posisi unsur pendamping head pada frasa verba bermacammacam jenis dan berbeda-beda posisinya. Pertama, tipe frasa verba dengan modifier terletak sebelum head. Pada tipe ini, dalam bahasa Inggris modifier dapat berupa auxiliary verb dengan struktur modal, perfect, progressive, passive dan berbagai kombinasinya kemudian diikuti oleh head. Sementara itu, dalam BB yang tidak mengenal adanya tenses, premodifier biasanya berupa modal, aspek, adverb, dan negasi. Kedua, tipe frasa verba dengan modifier terletak dibelakang head yang disebut postmodifier.

\section{KERANGKA TEORI}

Teori yang diterapkan dalam penelitian ini adalah Teori Struktural yang dikemukakan oleh Quirk dalam buku A Comprehensive Grammar Of The English Language dan Role and Reference Grammar $(R R G)$ atau Teori Peran dan Acuan yang dikemukakan oleh Van Valin. Teori struktural digunakan untuk mengkaji fungsi sintaksis frasa verba $\mathrm{BB}$ sedangkan teori $R R G$ hanya digunakan dalam mengkaji peran semantik argumen frasa verba BB.

$$
\begin{aligned}
& \text { 1. Meme-ne } \\
& \text { POS ibunya } \\
& \text { 'Ibunya tetap membuat sesajen'. }
\end{aligned}
$$

\section{PEMBAHASAN}

\section{FRASA VERBA BAHASA BALI}

Frasa verba merupakan kesatuan yang terbentuk dari dua unsure kata atau lebih dengan kata kerja sebagai head atau intinya, tetapi bentuk ini bukan merupakan klausa. Frasa verba mempuyai inti dan kata -kata lain yang mendampinginya. Frasa verba $\mathrm{BB}$ dapaat dilihat pada kalimat Mangkin ipun sampun padem'sekarang dia sudah mati'. Pada kalimat tersebut, yang merupakan frasa verba adalah sampun padem 'sudah meninggal' yang diisi aspek sampun sebagai modifiernya dan verba padem sebagai headnya.

\section{FRASA VERBA KOMPLEKS AD- VERB + VERBA}

Adverb atau kata keterangan merupakan kelas kata yang memberikan keterangan kepada kata lain, misalnya verba dan adjektiva. Adverb pada umumnya menerangkan tentang cara, tempat, waktu, dan bagaimana suatu peristiwa atau keadaan terjadi. Dalam BB terdapat beberapa adverbia yang dapat mendampingi verba dasar maupun turunan dan membentuk frasa verba, yaitu iteh, buin, masih, mara, enu/nu, pasti, mula, saling, tuah, wantah, tusing/tuara, tonden/durung. Perhatikan data berikut

$$
\text { ny-jait (Santha, 1981: 10) }
$$

INT membuat sesajen 


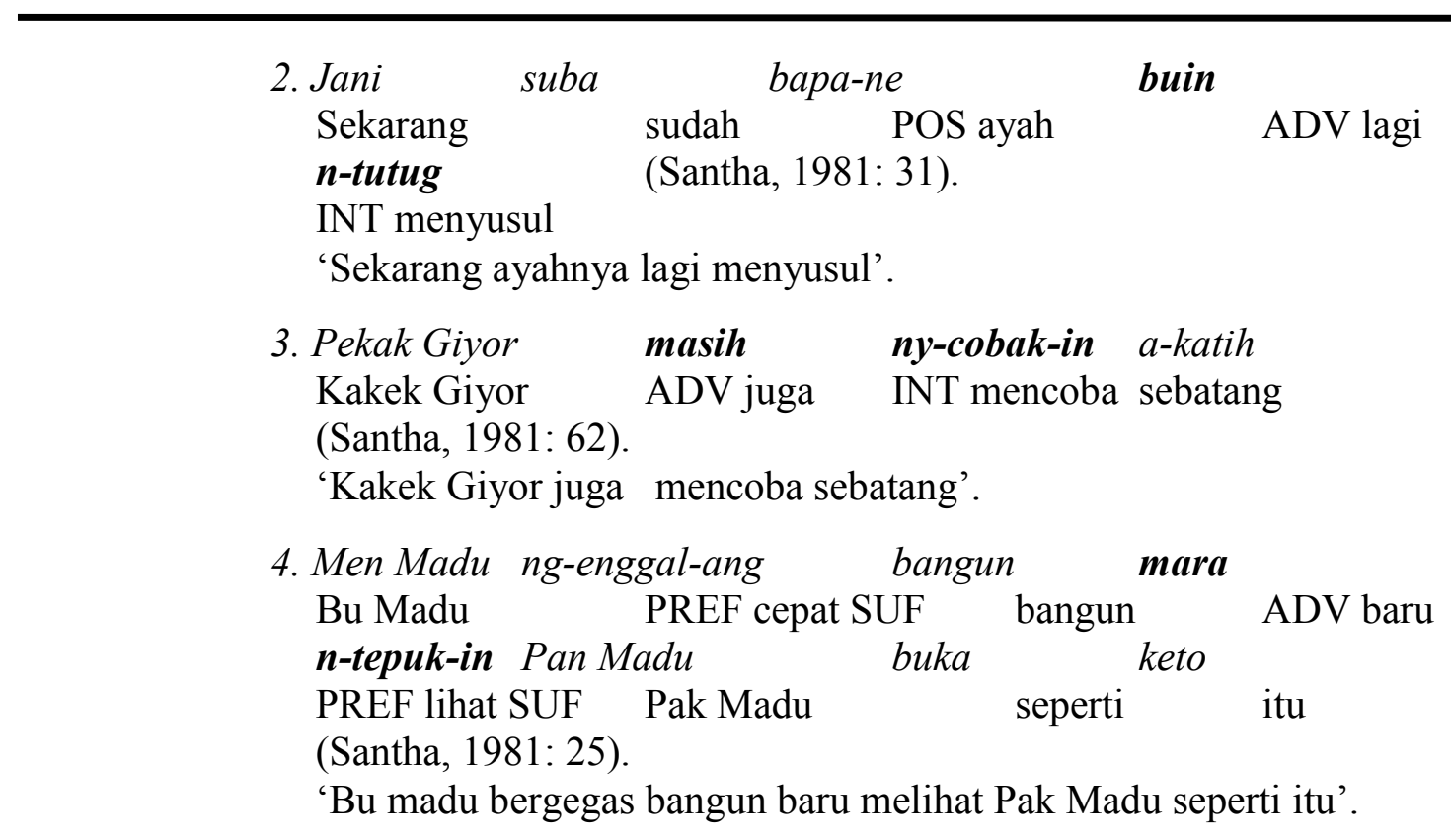

Terlihat dalam data (1) sampai (4), sejumlah adverbial berfungsi sebagai intensifier verba dasar dalam membentuk struktur frasanya. Terlihat pada data (1) iteh (tetap) merupakan adverbia yang berfungsi sebagai intensifier verba ny-jait (membuat sesajen). Gabungan kata iteh dan ngejait membentuk frasa verba dalam kalimat Meme-ne iteh ny-jait. Hal yang sama terlihat pada data (2), adverbia buin membentuk frasa verba buin n-tutuk dalam kalimat Jani suba bapa-ne buin. Dalam struktur frasa verba dimaksud, adverbia buin berfungsi sebagai intensifier yang muncul mendahului verba ntutuk dalam membentuk frasa verba buin n-tutuk. Hal yang sama terlihat pada data (3) dan (4), kata masih dan mara merupakan adverbial yang berfungsi sebagai intensifier verba $n y$ -cobak-in dan verba n-tepuk-in. Pada data
(3), gabungan kata masih dan ny-cobak-in membentuk frasa verba dalam kalimat Pekak Giyor masih ny-cobak-in a-katih. Sedangkan pada data (4), adverbia mara berfungsi sebagai intensifier yang muncul mendahului verba $n$-tepuk-in dalam membentuk frasa verba dalam kalimat $\mathrm{Men} \mathrm{Ma}$ du ng-enggal-ang bangun mara n-tepuk-in Pan Madu buka keto.

\section{FRASA VERBA KOMPLEKS PEN-}

\section{JANGKA KAMBANG PADA + VERBA}

Penjangka Kambang (PK) Pada dalam FVBB disini tidak diterjemahkan, tapi tetap dapat mendampingi verba untuk membangun frasa verba kompleks. Pada data, dia umumnya hadir setelah subjek yang berupa kelompok atau lebih dari satu orang. Frasa verba kompleks dengan unsur PK pada + verba sebagai berikut:

$\begin{array}{lll}\text { Makejang } & \text { pada } & \text { n-tengil } \\ \text { Semua } & \text { PK } & \text { PREF diam }\end{array}$




\begin{tabular}{|c|c|c|}
\hline$a d a$ & ane & sada \\
\hline ada & yang & - \\
\hline ng-gilgil-ang & karena & dingin-e \\
\hline PREF gigil SUF & karena & dingin $\mathrm{DE}$ \\
\hline
\end{tabular}

(Bawa, 2010: 116)

'Semua diam ada yang menggigil karena dingin'.

Pada data di atas, frasa verba terdiri atas dua unsur. Unsur yang pertama adalah PK pada sebagai unsur pendamping dan unsur kedua adalah verba turunan nengil 'diam' sebagai unsur pusat atau head. Verba nengil terdiri atas prefiks nasal $N$ - dan verba dasar tengil.

\section{FRASA VERBA KOMPLEKS ASPEK + VERBA}

Comrie (1978: 3-7) menyatakan bahwa aspek dan tenses adalah kategori gramatikal yang berhubungan dengan waktu. Walaupun memiliki ciri yang sama, tenses dan aspek merupakan kategori gramatikal yang berbeda. Van Valin dan La Polla (1997) mengatakan bahwa aspek merupakan kate-

gori gramatikal yang tidak menyatakan hubungan antara waktu tuturan dan waktu kejadian, tetapi kategori gramatikal yang menjelaskan tentang struktur waktu internal dari sebuah kejadian. Berbicara tentang aspek, yang dibicarakan adalah apakah kejadian itu selesai atau tidak, apakah kejadian itu sedang berjalan atau tidak, atau apakah kejadian itu terjadi dalam satu waktu atau diperpanjang. Untuk aspek ini, kategori utama yang ditemukan dalam beberapa bahasa adalah komplit dan tidak komplit atau dengan kata lain disebut dengan istilah selesai dan tidak selesai yang dalam istilah linguistiknya dikenal dengan istilah perfektif dan imperfektif. Perhatikan data perfektif (1) dan imperfektif (2) berikut

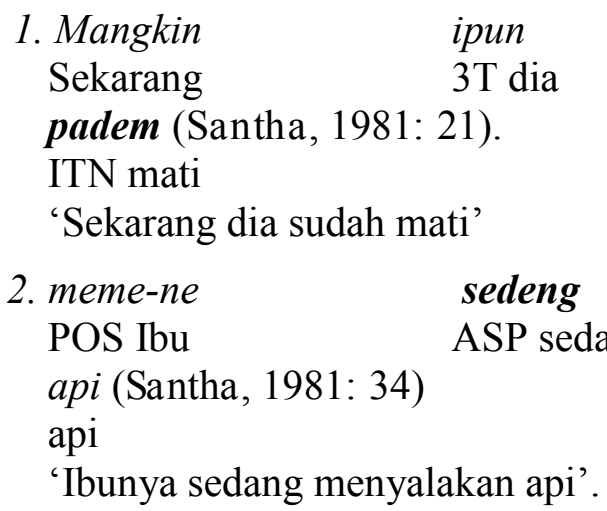

Terlihat pada data (1) dan (2), frasa verba terdiri atas dua unsur yaitu unsur pendamping dan unsur pusat. Pada data (1), kata sampun (sudah) merupakan unsur pen- damping dan verba dasar padem (mati) merupakan unsur pusatnya. Pada data (2), kata sedeng (sedang) merupakan unsur pendamping dan verba turunan ng-idup- 
FRASA VERBA KOMPLEKS MODAL

\section{+ VERBA}

Modal atau kata kerja bantu merupakan kata kerja yang muncul dan digunakan dengan kata kerja utama pada suatu klausa.

Dia digunakan bersama-sama dengan kata kerja pokok untuk memberikan makna tambahan pada klausa, yang tidak diberikan oleh kata kerja utama. Modal, jika mendampingi verba pokok maka akan membangun frasa verba

ma-temu (Santha, 1981: 12).

PREF temu

'Ia akan bertemu'.

\section{Tiang bisa ma-keneh (Santha, 1981: 81) \\ 1T saya MOD bisa INT merasakan \\ 'Saya bisa merasakan'.}

FRASA VERBA KOMPLEKS VERBA + KONJUNGSI + VERBA

Bawa menyatakan, apabila suatu frasa mempunyai fungsi atau kelas kata yang sama dengan semua unsur langsungnya, maka frasa ini termasuk tipe konstruksi endosentrik yang koordinatif. Dengan kata lain, semua unsurnya merupakan unsur pusat. Bawa juga menyatakan FVBB endosentrik yang koordinatif konstruksinya dapat berupa kelompok kata yang terdiri dari dua verba yang dihubungkan oleh kata penghubung dan dua buah verba tanpa kata penghubung. Dua verba yang dibuhungkan oleh kata penghubung contohnya megambel tur ngigel 'menabuh dan menari', maca tur nulis 'membaca dan menulis', nendang tur nyagur 'menyekap dan memukul'. Sementara yang tanpa kata penghubung, yaitu ngamah nginem 'makan minum', medem bangun 'tidur bangun', menek tuun 'naik turun'. Pendapat Bawa juga sesuai dengan pendapat Muslich yang menyatakan frasa verba endosentrik koordinatif sangat sederhana, bentuk ini merupakan dua verba yang dihubungkan dengan kata penghubung 'dan' atau 'atau'. Frasa ini juga dapat didahului dan diikuti oleh pewatas depan dan pewatas belakang yang memberi keterangan tambahan pada kedua verba. Lebih jelas mengenaik konstruksi ini, dapat dilihat pada contoh 'Mereka menangis dan meratapi nasibnya', 'Kami pergi atau menunggu dulu'. 'Sesudah ujian kami akan makan dan minum lagi di kantin (Muslich, 2010: 62). Frasa verba kompleks yang terdiri dari dua verba yang dihubungkan oleh konjungsi seperti data pada kalimat berikut

$\begin{array}{llll}\text { Ia } & \text { bangun } & \text { tur } & \text { ng-utah } \\ \text { 3T dia } & \text { TRAN bangun } & \text { KON dan } & \text { TRAN muntah } \\ d i & \text { puangan-e } & \text { (Santha, 1981: 24). } \\ \text { PREP di } & \text { puangan } & \\ \text { 'Dia bangun dan muntah di puangan'. }\end{array}$


Frasa verba bangun tur ng-utah (bangun dan muntah) terdiri atas tiga unsur. Unsurunsur tersebut adalah dua unsur verba bangun (bangun) dan ngutah (muntah), serta satu unsur konjungsi yaitu tur (dan).

\section{FUNGSI SINTAKSIS FRASA VERBA}

\section{BAHASA BALI}

Setiap unsur yang membentuk sebuah kalimat memiliki fungsi sintaksisnya masingmasing. Jika ditinjau dari segi fungsinya dalam kalimat, frasa verba menduduki

a Frasa Verba Berfungsi Subjek: fungsi sebagai predikat. Fungsi frasa verba yang mengisi fungsi predikat dalam kalimat didukung oleh pernyataan Chaer (2009: 138) yang menyebutkan bahwa frasa verba adalah frasa yang mengisi atau menduduki fungsi Predikat pada sebuah klausa. Akan tetapi, di sisi lain frasa verba dapat pula memiliki fungsi lain, yaitu fungsi subjek, objek, pelengkap, keterangan, dan apositif (Muslich, 2010: 62). perhatikan data berikut:

$\begin{array}{llll}\text { Saling } & \text { tulung } & \text { mula } & \text { wat nadi } \\ \text { ADV saling } & \text { INT tolong ADV memang } & \text { urat nadi } \\ \text { krama } & \text { banjar Bali-ne (Bawa, 2010: 22) } & \\ \text { warga } & \text { dusun Bali DEF } & \\ \text { 'Saling tolong memang urat nadi warga dusun Bali'. }\end{array}$

b. Frasa Verba Berfungsi Predikat:

$\begin{array}{lll}\text { Bibi mula } & \text { ng-antiang } & \text { cening } \\ \text { Bibik ADV memang } & \text { PREF tunggu } & \text { kamu } \\ \text { (Santha, 1981: 13) } & & \\ \text { 'Bibik memang menunggu kamu'. } & \end{array}$

c. Frasa Verba Berfungsi Objek:

$\begin{array}{lll}\text { Nyoman Santosa } & \text { lan } & \text { timpal-timpal-ne } \\ \text { Nyoman Santosa } & \text { KON dan } & \text { POS teman-teman } \\ \text { n-terus-ang } & \text { ma-lagar-an } & \\ \text { PREF terus SUF } & \text { PREF camilan SUF } & \end{array}$

(Santha, 1981: 140)

'Nyoman Santosa dan teman-temannya meneruskan makan camilan'

d. Frasa Verba Berfungsi Pelengkap:

$\begin{array}{lll}\text { Ng-kanti } & \text { jam } & \text { roras } \\ \text { PREF sampai } & \text { jam } & \text { dua belas } \\ \text { Nyoman Santosa } & \text { lan } & \text { timpal-timpal-ne } \\ \text { Nyoman Santoda } & \text { KON dan } & \text { POS teman-teman } \\ \text { mara } & \text { suud } & \text { ma-sadeg-an } \\ \text { ADV baru } & \text { TRAN selesai } & \text { PREF istirahat SUF }\end{array}$

(Santha, 1981: 140)

'Sampai jam dua belas Nyoman Santosa dan teman-temannya baru selesai beristirahat'. 
e. Frasa Verba Berfungsi Keterangan:

$\begin{array}{lcc}\text { Jani } & \text { makejang } & \text { pada } \\ \text { Sekarang } & \text { semua } & \text { PK } \\ \text { luas } & \text { lakar } & \text { n-delok-in } \\ \text { INT pergi } & \text { MOD akan } & \text { PREF lihat SUF } \\ \begin{array}{l}\text { pengumuman-e } \\ \text { pengumuman DEF }\end{array} & & \text { (Santha, 1981: 35) } \\ \text { 'Sekarang semua sama pergi akan melihat pengumuman' }\end{array}$

f. Frasa Verba Berfungsi Apositif:

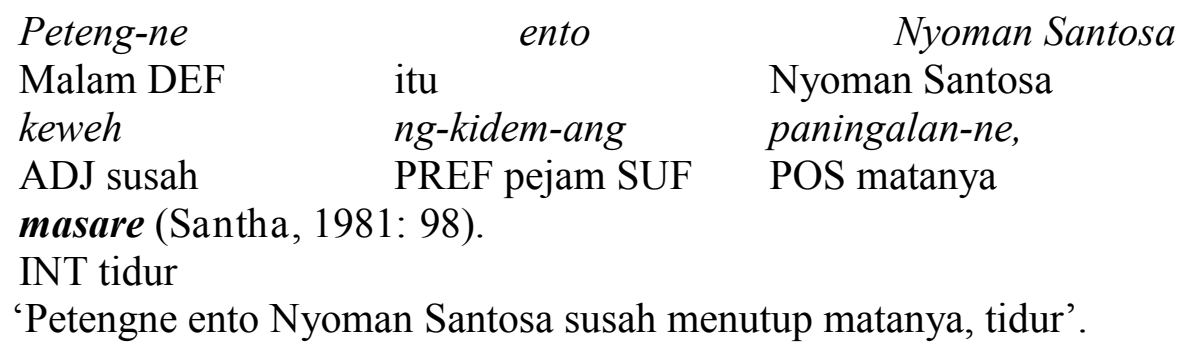

PERAN SEMANTIK ARGUMEN FRA-

\section{SA VERBA BAHASA BALI}

\section{Agen}

Agen merupakan peran yang biasanya diisi oleh kata benda atau frasa nomina. Agen merupakan pelaku yang melakukan tindakan atau aksi sesuai dengan yang diinginkannya. Dengan kata lain, agen adalah instigator yang melakukan tindakan atau peristiwa, dengan sengaja dan dengan tujuan tertentu. Perhatikan data berikut :

$\begin{array}{llll}\text { Sampi-ne } & \text { iteh } & \text { ng-amah } & \text { padang } \\ \text { POS Sapi } & \text { ADV tetap } & \text { PREF makan } & \text { rumput } \\ \text { disisin } & \text { telabah-e } & \text { (Santha, 1981: 7). } & \\ \text { dipinggir } & \text { parit DEF } & & \\ \text { 'Sapinya tetap makan rumput dipinggir parit'. } & \end{array}$

Pada data di atas, argumen sampine memiliki peran agen karena argument tersebut merupakan pelaku dari predikat yang diisi oleh frasa verba iteh ngamah 'tetap makan'. Sebagai inti frasa, frasa verba iteh ngamah diisi oleh verba aksi.

\section{B. Penyebab}

Argumen yang berfungsi sebagai penyebab (efektor) umumnya merupakan pelaku tindakan atau peristiwa yang dilakukan, baik sengaja maupun tidak sengaja. Sehubungan dengan istilah penyebab (efektor) telah diketahui bahwa dalam konstruksi kausatif terdiri atas dua situasi mikro yang melibat dua istilah, yaitu penyebab dan pesebab yang salah satunya memiliki perilaku yang serupa dengan pengakibat. Dua situasi mikro tersebut digambarkan dengan adanya suatu peristiwa yang terjadi (causing event) yakni penyebab (causer) melakukan sesuatu agar peristiwa lain terjadi (caused event) dan dalam peristiwa yang disebabkan (caused event) tersebut, tersebab (causee) mengalami kegiatan atau mengalami perubahan kondisi akibat perbuatan penyebab (causer). Uraian di atas menggambarkan 
bahwa penyebab dan pesebab berada dalam suatu kondisi yang serupa, yaitu dalam peristiwa yang terjadi. Hanya dalam peristiwa yang terjadi masing-masing memiliki peran yang berbeda. Seperti yang telah diuraikan di atas penyebab dan pengakibat merupakan argumen yang menyebabkan terjadinya peristiwa lain, sedangkan pesebab adalah argumen yang mengalami peristiwa yang disebabkan oleh penyebab. Akan tetapi, antara penyebab dan pengakibat memiliki

$\begin{array}{lll}\text { Pa-temu-ne } & \text { jani } & \text { masih } \\ \text { PREF temu DEF } & \text { ADV sekarang } & \text { ADV juga } \\ \text { n-tumbuh-ang } & \text { rasa } & \text { asih } \\ \text { PREF tumbuh SUF } & \text { rasa } & \text { kasih } \\ \text { lan } & \text { liang (Santha, 1981: 93) } \\ \text { KON } & \text { bahagia } \\ \text { 'Pertemuan sekarang ini juga menumbuhkan rasa kasih dan sayang' }\end{array}$

\section{Pengalami}

Pengalami adalah peran argumen yang mengalami keadaan atau perasaan internal. Untuk mendukung pemahaman tersebut, Parera (1993:125) mengatakan bahwa peran argumen ini menyatakan sesuatu yang mengalami dan kena suatu peristiwa psikologis, baik sensasi, emosi, maupun kognitif. Selain itu, Van Valin dan Foley (1984: 29) menegaskan bahwa pengalami adalah suatu peran argumen yang tidak melakukan, menyelenggarakan, memain-

Mangkin ipun
Sekarang 3T dia
(Santha, 1981: 21).
'Sekarang dia sudah mati'

Pada data di atas, argumen pengalami diisi oleh argumen ipun 'dia'. Argumen ipun 'dia' merupakan argumen bernyawa. sedikit perbedaan pada dampak tindakan yang dihasilkan terhadap argumen pesebab. Dampak peristiwa yang dilakukan oleh penyebab tidak terlalu kuat sehingga tidak secara langsung memengaruhi tersebab. Dampak peristiwa yang dilakukan oleh pengakibat sangat kuat sehingga secara langsung memengaruhi tersebab. Untuk lebih jelasnya, mari kita lihat contoh berikut

kan, memulai, memprakarsai atau mengontrol keadaan. Apabila dengan saksama dipahami, penyebutan pengalami pada sebuah argumen, mengacu pada argumen bernyawa karena berdasarkan logika hanya yang bernyawa yang merasakan atau mengalami sesuatu. Akan tetapi, dalam desertasi Seri Satyawati (2009) disebutkan argumen yang berperan pengalami dapat dimiliki, baik oleh argumen bernyawa maupun argumen tidak bernyawa. Data berikut menggambarkan argumen pengalami:

$$
\begin{array}{ll}
\text { sampun } & \text { padem } \\
\text { ASP sudah } & \text { ITN mati }
\end{array}
$$

Pada umumnya, argumen yang berberan sebagai alat berupa entitas yang tidak bernyawa yang digunakan oleh agen dalam melakukan tindakan. Dengan kata lain, alat 
dapat dikatakan sebagai instrumen yang digunakan oleh pelaku untuk melakukan tindakan. Peran argumen sebagai alat dapat dilihat pada data berikut

$\begin{array}{llll}\text { Sa-suba-ne } & \text { dedeh } & \text { angkihan-ne } & \text { Gusti Ayu Jinar } \\ \text { PREP telah SUF } & \text { normal } & \text { POS nafas } & \text { Gusti Ayu Jinar } \\ \text { mara } & \text { saput-in-a } & \text { raga-ne } & \text { baan } \\ \text { baru } & \text { selimut SUF } & \text { POS badan } & \text { dengan } \\ \text { anduk } & \text { lan } & \text { kamben } & \text { apang } \\ \text { handuk } & \text { KON dan } & \text { kain } & \text { agar }\end{array}$

anget (Santha, 1981: 95).

hangat

'Setelah normal nafas Gusti Ayu Jinar baru diselimuti badannya dengan handuk dan kain agar hangat'.

Pada data di atas terlihat sangat jelas entitas anduk lan kamben 'handuk dan kain' merupakan alat yang digunakan untuk menyelimuti badan.

\section{e. Pasien}

Pasien adalah argumen, baik bernyawa

$\begin{array}{lll}\text { Sampi-ne } & \text { iteh } & \text { ng-amah } \\ \text { POS Sapinya } & \text { ADV tetap } & \text { PREF TRAN makan } \\ \text { padang } & \text { di sisin } & \text { telabah-e (Santha, 1981: 7) } \\ \text { rumput } & \text { PREP di pinggir } & \text { parit DEF } \\ \text { 'Sapinya tetap makan rumput dipinggir parit'. }\end{array}$

Pada data di atas, unsur padang 'rumput' merupaka argumen yang yang diikat oleh frasa verba dan berperan sebagai pasien karena padang 'rumput' merupakan pengalam dari aksi yang dilakukan oleh agen sampine 'sapinya'.

\section{f. Tema}

Selain peran di atas, ada pula argumen yang berperan sebagai tema. Tema merupakan peran sebuah argumen yang diletakkan maupun tidak bernyawa yang berada dalam suatu keadaan atau mengalami perubahan keadaan yang diakibatkan oleh verba. Perhatikan data beriku di suatu tempat atau peran sebuah argumen yang mengalami suatu perpindahan lokasi. Peran ini hampir sama dengan peran patient, perannya dikenai aktifitas atau aksi dari verba yang dilakukan oleh agen. Yang membedakan peran tema dengan pasien, peran ini mengalami perpindahan atau pergerakan yang diakibatkan aktivitas atau aksi sesuai verbanya. Perhatikan data berikut 


$\begin{array}{lll}\text { Di } & \text { dagang-e } & \text { Nyoman Santosa } \\ \text { PREP } & \text { dagang DEF } & \text { Nyoman Santosa } \\ \text { m-pesu-ang } & \text { tas plastik } & \text { anggo-na } \\ \text { PREF keluar SUF } & \text { tas plastik } & \text { dipakai SUF } \\ \text { wadah } & \text { gedang } & \text { lan } \\ \text { tempat } & \text { pepaya } & \text { KON dan } \\ \text { serombotan } & \text { (Santha, 1981: 52) } & \\ \text { nama masakan serombotan } & \end{array}$

'Di warung Nyoman Santosa mengeluarkan tas plastik dipakai tempat pepaya dan serombotan'.

Pada data di atas, verba mesuang 'mengeluarkan' menunjukkan adanya perpindahan argument tas plastik dari dalam ke luar sehingga tas plastik berperan sebagai tema.

\section{g. Asal}

Peran asal digunakan dalam variasi kasus, di mana terdapat keambiguan antara penerima dan sasaran. Dijelaskan bahwa jika terdapat perpindahan objek, posisi akhir merupakan penerima. Jika argumen yang berfungsi sebagai objek bergerak, argumen pada posisi akhir adalah tujuan. Dalam situasi yang sama, posisi awal (subjek) merupakan sumber dan objek merupakan tema. Misalnya, dalam David giving a book to Kristen. Peran argumen David dapat sebagai agen dan sebagai sumber, sedangkan dalam Yolanda buying the dog from Bill, peran Yolanda dapat sebagai agen dan penerima. Sementara itu, Saeed memiliki pernyataan lain. Kata source berarti dari mana sesuatu berasal atau bersumber. Pengertian peran asal pada argumen kalimat secara umum sama seperti arti leksikal kata source. Saeed menyatakan 'source is the entity from which something moves, either literally or metaphorically (Saeed, 1997: 141). Pada definisi tersebut dijelaskan bahwa sumber dapat berupa literal dan non literal atau bukan hanya dari sesuatu yang literal tapi juga dapat berupa sesuatu yang abstrak. Peran source dapat dilihat pada kalimat 'The plane came back from Kinshasa 'pesawat datang dari Kinshasa', We got the idea from a French magazine 'Kami dapat ide dari majalah Perancis' (Saeed, 1997: 141). Peran source pada kalimat-kalimat tersebut terdapat pada frasa preposisional from Kinshasa 'dari Kinshasa' dan from a French magazine 'dari majalah Perancis'. Perhatikan data berikut

Krama banjar-e

Warga dusun DEF jani

ADV sekarang $\begin{array}{ll}\text { lan } & \text { desa-ne } \\ \text { suba } & \text { desa DEF }\end{array}$

ASP sudah PREF kembali 


\begin{tabular}{lll}
\hline $\boldsymbol{u l i}$ & sema & nuju \\
PREP dari & kuburan & ke \\
umah-ne & suang-suang (Santha, 1981: 21). \\
POS rumah & masing-masing \\
'Warga dusun dan desa sekarang & sudah kembali dari kuburan ke \\
& rumahnya masing-masing'.
\end{tabular}

Frasa preposisi uli sema 'dari kuburan' merupakan argument yang diikat oleh frasa verba suba matulak 'sudah kembali'. Frasa tersebut terdiri dari preposisi uli yang berarti 'dari' yang jika diikuti oleh nama tempat, maka preposisi itu menerangkan bahwa tempat yang mengikuti preposisi tersebut merupakan asal atau sumber. Pada data di atas, argument uli setra 'dari kuburan' berperan sebagai sumber karena menunjukkan agen karma banjare lan desane 'warga

\section{h. Lokatif}

Lokatif adalah peran argumen sebagai tempat. Argumen yang berperan sebagai lokatif berfungsi sebagai ajung sehingga bukan merupakan argumen inti. Peran ini menjelaskan atau memberikan informasi mengenai lokasi dimana aksi terjadi di dalam kalimat yang dapat diisi oleh frasa preposisi. Perhatian data berikut : dusun dan desa' kembali dari kuburan.

$\begin{array}{llll}\text { Manawi } & \text { benjang } & \text { ipun } & \text { sampun } \\ \text { Barangkali } & \text { besok } & \text { 3T dia } & \text { ASP sudah } \\ \text { puput } & \text { ma-tanem } & \text { di } & \text { setra } \\ \text { INT selesai } & \text { PREF kubur } & \text { PREP di } & \text { kuburan } \\ \text { (Santha, 1981: 20). } & & \\ \text { 'Barangkali besok dia sudah selesai dikubur di kuburan'. }\end{array}$

Pada data di atas, frasa preposisional di setra 'di kuburan' merupakan argumen yang diikat oleh frasa verba sampun puput matanem 'sudah selesai di kubur'. Frasa preposisional di setra menerangkan lokasi dimana terjadinya aksi, sehingga merupakan argument yang berperan location.

\section{SIMPULAN}

Struktur FVBB dapat berupa FV sederhana dan FV kompleks. FVBB seder- hana terdiri dari unsur pusat (head) saja tanpa modifier. FVBB kompleks terdiri dari, 1) FV endosentrik atributif yang terdiri atas modifier dan head, 2) FV endosentrik koordinatif yaang terdiri dari dua verba yang dihubungkan oleh konjungsi (V KONJ V). FVBB kompleks yang terdiri dari modifier dan head dapat diisi oleh $(\mathrm{ADV}+\mathrm{V}),(\mathrm{PK}+\mathrm{V}),(\mathrm{NEG}+\mathrm{V}),(\mathrm{ADV}$ $+\mathrm{NEG}+\mathrm{V}),(\mathrm{ASP}+\mathrm{V}),(\mathrm{ASP}+\mathrm{ADV}+$ $\mathrm{V}),(\mathrm{ADV}+\mathrm{ASP}+\mathrm{V}),(\mathrm{MOD}+\mathrm{V}),(\mathrm{MOD}$ $+\mathrm{ADV}+\mathrm{V}),(\mathrm{MOD}+\mathrm{V}+\mathrm{ADV}),(\mathrm{ASP}+$ 
$\mathrm{NEG}+\mathrm{MOD}+\mathrm{V})$ dan $(\mathrm{NEG}+\mathrm{MOD}+$ V). Berdasarkan penelitian ini, adverb BB yang dapat mendampingi verba dan membangun frasa verba ,yaitu iteh/tetep 'tetap', buin 'lagi', masih 'juga', mara 'baru', enu/ nu 'masih', pasti 'pasti', mula 'memang', saling 'saling', dan tuah/wantah 'hanya'. Kemudian ditemukan pula adverb dengan makna 'ingkar' (negasi), yaitu tusing/tuara 'tidak' dan durung/tonden 'belum'. Ditemukan juga Penjangka Kambang (PK) pada yang tidak diterjemahkan, tapi dapat menjadi modifier dari FVBB. Sementara itu, pemarkah aspek dalam BB yang dapat mendampingi verba dan membangun frasa verba terdiri dari aspek perfektif dan imperfektif yang berupa kata suba/sampun 'sudah'(perfektif) dan sedek/sedeng 'sedang' (imperfektif). Modal yang dapat mendampingi verba untuk membentuk frasa verba, yaitu lakar/jagi 'akan', bisa 'bisa'. Pada FVBB kompleks koordinatif, konjungsi yang dapat menghubungkan verba untuk membangun frasa verba, yaitu tur/ lan 'dan'.

Dalam penelitian mengenai fungsi sintaksisnya, FVBB pada umumnya berfungsi sebagai predikat, akan tetapi juga dapat berfungsi sebagai subjek, objek, pelengkap, keterangan, dan apositif.

Argumen yang diikat oleh FVBB dalam peran umum dapat berperan sebagai actor dan undergoer dengan peran khususnya masing-masing. Peran khusus dari actor dan undergoer yang ditemukan dalam BB, yaitu agen, pengakibat, pengalami, pasien, tema, asal, lokatif.

\section{UCAPAN TERIMA KASIH}

Pada kesempatan ini penulis menyampaikan ucapan terima kasih kepada Mitra Bestari yang telah memberikan masukanmasukan yang bermanfaat bagi perbaikan artikel ini.

\section{DAFTAR PUSTAKA}

Alwi, Hasan, dkk. 2003. Tata Bahasa Baku Bahasa Indonesia. Edisi Ketiga. Jakarta: Balai Pustaka.

Anom, I Gst. K., dkk., 1983. Tata Bahasa Bali. Denpasar: PT. Mahabhakti offset.

Bawa, I Wayan, dkk., 1979. Sintaksis Bahasa Bali. Jakarta: Pusat Pembinaan dan Pengembangan Bahasa.

Bawa, I Gst. Putu, 2010. Jangkrik Maenci. Denpasar: Pustaka Ekspresi.

Chaer, Abdul, 2009. Sintaksis Bahasa Indonesia. Jakarta: Rineka Cipta.

Kardana, I Nyoman, 2004. Konstruksi Refleksif Dan Diatesis Medial Bahasa Bali (Disertasi). Denpasar: Universitas Udayana.

Manda, Nyoman, 2008. Sawang-Sawang Gamang. Gianyar : Pondok Tebawutu.

Muslich, Masnur, 2010. Garis-Garis Besar Tatabahasa Baku Bahasa Indonesia. Bandung: PT Refika Aditama.

Quirk, Randolph, 1985. A Comprehensive Grammar Of The English Language. England: Longman.

Saeed, John. I., 1997. Semantics. London: Blackwell Publishers.

Santha, Jelantik, 1981. Tresna Lebur Ajur Setonden Kembang. Denpasar: Dinas Pendidikan dan Kebudayaan provinsi Bali. 
Satyawati, Seri, 2009. Valensi Dan Relasi Sintaksis Bahasa Bima (Disertasi). Denpasar. Universitas Udayana.

Sudaryanto, 1986. Metode Linguistik. Yogyakarta: Gadjah Mada University Press.

Sudaryanto, 1993. Metode dan Aneka Teknik Analisis Bahasa. Yogyakarta; Dutawacana University Press.

Van Valin Robert D., Jr. and William A. Foley, 1980. Role and Reference Grammar dalam Moravcsik and Wirth, editors. Cambridge: Cambridge University Press.

Van Valin, Robert D.,Jr dan Randy J. la Polla. 1997. Syntax: Structure, Meaning, and Function. Cambridge: Cambridge University Press.

Van Valin, Robert D., Jr. 2005. Exploring the Syntax-Semantics Interface. First Edition. Cambrige: Cambrigde University Press.

Verhaar, J. W.M., 1990. A sas-asas Linguistik Umum. Yogyakarta: Gadjah Mada University Press.

Verhaar, J. W. M. 2008. A sas-asas Linguistik Umum. Jogya: Gajah Mada University Press.

Warna, I Wayan, 1983. Tata Bahasa Bali. Denpasar: Dinas Pendidikan dan Kebudayaan provinsi Bali. 